2. Vorobyova AV. Osoblyvosti perebihu khronichnoho hastroduodenitu u ditey. Visnyk Novykh medychnyy tekhnolohiy. 2016 roku; 12; 1-2; 30-35. [in Ukrainian].

3. Reyzvykh OE., Shnayder SA., Noneva ALE. Vzayemozv'yazok chastoty stomatolohichnykh zakhvoryuvan' $\mathrm{z}$ rivnem somatychnoho zdorov'ya ditey (Ohlyad literatury). Innovatsiyi v stomatolohii 2014;3; 125-133. [in Ukrainian].

4. Shtompel' AV. Rol' defenziny v patohenezi osnovnykh stomatolohichnykh zakhvoryuvan' u ditey z khronichnymy zakhvoryuvannyamy shlunkovo-kyshkovoho traktu. Suchasna stomatolohiya. 2018; 1 (90); 50-53. [in Ukrainian].

5. Bauman SS., Sheshukova OV. Poshirenist' khronichnoho kataral'ni hinhivitu u ditey riznoho viku $\mathrm{z}$ hastroduodenitom. Visnik problem biolohiyi y medytsyny - 2020; 1 (155); 17-20. [in Ukrainian].

DOI https://doi.org/10.30525/978-9934-588-81-5-1.6

\title{
ГІСТОЛОГІЧНІ ЗМІНИ СТРУКТУРНИХ КОМПОНЕНТІВ ЯСЕН ПРИ ПАРОДОНТИТІ НА ФОНІ ГАСТРИТУ
}

\author{
Беденюк О. С. \\ кандидат медичних наук, \\ асистент кафедри хірургічної стоматології
}

Тернопільський національний медичний університет

імені І. Я. Горбачевського Міністерства охорони здоров'я Украӥни

Беденюк О. А.

кандидат медичних наук, доцент, асистент кафедри ортопедичної стоматології

Тернопільський національний медичний університет

імені І. Я. Горбачевського Міністерства охорони здоров'я Украӥни

Воробець А. Б.

кандидат медичних наук, дочент, асистент кафедри ортопедичної стоматологіі

Тернопільський національний медичний університет

імені І. Я. Горбачевського Міністерства охорони здоров'я Украӥни м. Тернопіль, Україна

Запальні захворювання тканин пародонту на сьогодні є чи не найважливішою проблемою стоматології, що має не тільки медичне, але й величезне соціальне значення, яке зумовлено широкою поширеніс- 
тю пародонтитів, ураженням осіб молодого віку, можливістю впливу пародонтиту на виникнення соматичної патології, відсутністю ефективних методів діагностики, профілактики та лікування $[1$, с. 9; 2, с. 20]. Поширеність пародонтиту в різних країнах світу становить 50-90 \% [3, с. 5], Україна також належить до країн зі значною розповсюдженістю захворювань пародонта - залежно від регіону та віку обстежених вона досягає 85-95\% [4, с. 10].

Епідеміологічні дослідження чітко підтверджують, що цукровий діабет, гіпертонічна хвороба, септичний ендокардит, сечокам'яна хвороба, гепатити і ряд інших захворювань 3 абсолютною закономірністю поєднуються 3 ураженням пародонту [5, с. 1016; 6, с. 45]. Не дослідженими залишаються патоморфологічні механізми розвитку індукованого ендотоксином грамнегативної мікорофлори ліпополісахаридом пародонтиту, асоційованого $з$ хронічним атрофічним гастритом.

Мета роботи - дослідити патоморфологічні зміни в тканинах пародонту при генералізованому ліпополісахаридному пародонтиті, асоційованому з хронічним атрофічним гастритом.

Матеріали і методи дослідження. Досліди виконані на білих безпородних щурах-самцях масою тіла 160-180 г. У процесі роботи використано 30 тварин. Всі етапи експериментів виконані згідно з Міжнародними вимогами гуманного поводження 3 тваринами відповідно до «Свропейської конвенції із захисту хребетних тварин, що використовуються в експериментальних та інших наукових цілях» (Страсбург, 1986).

Піддослідні тварини були розділені на наступні групи: I - інтактні щури (контроль); II - тварини з моделлю генералізованого ліпополісахаридного пародонтиту. Щурам цієї групи вводили в тканини ясен ліпополісахарид (ЛПС) Е. Coli («Sigma-Aldrich», США). ЛПС розводили на стерильному фізіологічному розчині і вводили за допомогою шприца ін'єкційного інсулінового в дозі 40 мікролітрів (1 мг/мл) через день протягом 2-х тижнів; III - щури з ліпополісахаридним пародонтитом на тлі хронічного атрофічного гастриту. У тварин цієї групи викликали атрофічний гастрит шляхом інтрагастрального введення протягом 6 тижнів 2\% саліцилату натрію. Розвиток атрофічного гастриту підтверджували гістологічними дослідженнями.

Для морфологічного дослідження пародонту виділяли фрагмент верхньої щелепи. Шматочки фрагментів тканин пародонту фіксували в $10 \%$-му розчині забуференого нейтрального формаліну протягом двох тижнів з триразовою зміною фіксуючого розчину. Після фіксації у формаліні проводили декальцинацію тканин щелепи. Потім матеріал відмивали в проточній воді, зневоднювали у розчинах етилового спирту зростаючої концентрації й ущільнювали парафіном. Виготовлення серійних парафінових зрізів товщиною 4-6 мкм проводилося на 
санному мікротомі МC-1. Фарбування препаратів здійснювалося гематоксиліном і еозином. Гістологічні препарати вивчали за допомогою світлового мікроскопа SEOSCAN та фотодокументували за допомогою відеокамери Vision CCD Camera.

Результати дослідження. Мікроскопічні дослідження ясен щурів при пародонтиті на фоні гастриту показали, що зміни їх структурних компонентів подібні до таких у групі тварин 3 пародонтитом, проте вони були більш виражені. У епітеліальній пластинці слизової оболонки крім потовщення рогового шару спостерігались ділянки його відшарування та утворення інвагінацій, заповнених роговими лусочками. Це відображає розвиток гіперкератозу в епітелії вільної частини ясен.

Товщина остистого і рогового шарів зменшена навіть порівняно 3 групою тварин з експериментальним пародонтитом. У епітеліоцитах базального шару каріоплазма ядер базофільна, вони невеликі. Між такими клітинами наявні мігруючі лімфоцити. У остистому шарі чисельність клітин зменшена навіть у рядах. Відсутні чіткі плазмолеми між клітинами.

Гістологічно у епітеліальній пластинці слизової виявляються ділянки, у яких мігруючі лімфоцити утворюють скупчення, що свідчить про значну деструкцію нижніх шарів клітин і розвиток запального процесу.

Розвиток більш значного пошкодження епітеліальної пластинки слизової оболонки виявляється також у ділянках борозни та прикріплення. На поверхні епітеліальної пластинки борозни спостерігається шар злущених клітин, у якому наявні пошкоджені і загиблі лейкоцити. Запальна реакція і вихід лімфоцитів на поверхню виявляється в більш тонких ділянках епітеліальної пластинки. У базальному шарі відмічаються клітини 3 невеликими базофільними ядрами, невеликою площею цитоплазми. Мітотичний поділ епітеліоцитів виявляється рідко. У остистому шарі мало рядів клітин, як і у зернистому.

У слизовій оболонці ясен тварин відмічаються значні зміни структурних компонентів мікроциркуляторного русла. Артеріоли мають потовщену стінку, вузькі просвіти. Просвіти венул і капілярів навпаки значно збільшені, кровонаповнені, а стінки їх витончені. В окремих ділянках наявні пошкодження стінки судин і крововиливи. Такий стан судин свідчить про порушення кровотоку і застійні явища.

У ділянці борозни власна пластинка значно інфільтрована, скупчення лейкоцитів наявні у периваскулярному просторі, а також у сполучній тканині власної пластинки слизової оболонки ясен.

У власній пластинці слизової оболонки ясен наявний набряк аморфного компоненту міжклітинної речовини, деструктивні зміни волокон. У сітчастому шарі сполучної тканини вільної частини ясен наяв- 
ний виражений набряк. Ще більший набряк і лейкоцитарна інфільтрація спостерігаються у ділянках борозни і прикріплення.

Ми спостерігали деяке погіршання патоморфологічної картини структур пародонту у тварин з пародонтитом на фоні атрофічного гастриту порівняно 3 тваринами 3 пародонтитом без гастриту. Може бути декілька механізмів такого негативного впливу супутньої гастроентерологічної патології на тканини пародонту. При хронічному гастриті можуть посилено вироблятися травні гормони (гастрин, холецистокінін тощо), які, діючи прямо чи опосередковано на С-клітини щитоподібної залози, збільшують продукцію кальцитоніну, що призводить до виснаження С-клітин щитоподібної залози і збільшення вироблення паратиреоїдного гормону, що, у свою чергу, викликає резорбтивні процеси в сполучній тканині пародонта. Крім того, при хронічному гастриті порушується ряд регуляторних механізмів, що створює умови для розвитку пародонтиту. Зокрема, змінюється імунна реактивність організму (має місце недостатня кількість активних форм нейтрофілів, знижується вміст Т-лімфоцитів і їх функціональна активність), виникає ендокринний дисбаланс, відбуваються порушення мікроциркуляції, нейрогуморальної регуляції, змінюється метаболізм сполучної тканини, мінеральний обмін, виникає дефіцит вітамінів. Все це призводить до ослаблення резистентності організму і на цьому фоні під впливом ендотоксинів грамнегативних бактерій виникає виражена запальна реакція тканин ротової порожнини.

Висновки. При експериментальному пародонтиті на фоні гастриту виявляються значні пошкодження всіх структурних компонентів пародонту. Реорганізація епітелію слизової оболонки ясен, як вільної так і ділянок борозни та прикріплення характеризується вираженим потовщенням зроговілого шару, зменшенням остистого шару, деструкцією епітеліоцитів базального шару. Ще в більшому ступені зростає лімфоцитарна інфільтрація внаслідок руйнування міжклітинних контактів та розширення міжклітинних просторів.

\section{Лiтература:}

1. Al-Harthi L. S., Cullinan M. P., Leichter J. W. Periodontitis among adult populations in the Arab World. Int. Dent. J. 2013. T 63, № 1. P. 7-11.

2. Otomo-Corgel J., Pucher J. J., Rethman M. P. State of the science: chronic periodontitis and systemic health. J. Evid. Based. Dent. Pract. 2012. 12, № 3. P. 20-28.

3. Kye W., Davidson R., Martin J., Engebretson S. Current status of periodontal risk assessment. J. Evid. Based. Dent. Pract. 2012. 12, № 3. P. 2-11. 
4. Батіг В. М. Поширеність і інтенсивність захворювань пародонту в працівників підприємств хімії органічного синтезу. Буковин. мед. вісник. 2010. Т. 14, № 1. С. 9-13.

5. Tamaki N., Takaki A., Tomofuji T. Stage of hepatocellular carcinoma is associated with periodontitis. J. Clin. Periodontol. 2011. 38, № 11. P. 1015-1020.

6. Amano A., Inaba H. Cardiovascular diseases and periodontal diseases. Clin. Calcium. 2012. 22, № 1. P. 43-48.

DOI https://doi.org/10.30525/978-9934-588-81-5-1.7

\title{
IDENTIFYING THE PREDICTORS OF RECURRENCE OF ENDOMETRIUM POLYPS IN WOMEN OF REPRODUCTIVE AGE
}

\author{
Beniuk V. O.
}

Doctor of Medical Sciences, Professor, Head of the Department of Obstetrics and Gynecology № 3

Bogomolets National Medical University

\section{Perepadia O. V.}

Candidate of Medical Sciences,

Doctor-Oncologist,

Feofania Clinical Hospital of the State Administration of Affairs

\section{Goncharenko V. M.}

Doctor of Medical Sciences, Professor,

Professor at the Department of Obstetrics and Gynecology № 3

Bogomolets National Medical University

Kovaliuk T. V.

Candidate of Medical Sciences,

Associate Professor at the Department of Obstetrics and Gynecology № 3

Bogomolets National Medical University

\section{Kravchenko Yu. V.}

Postgraduate Student at the Department of Obstetrics and Gynecology № 3 Bogomolets National Medical University

$$
\text { Kyiv, Ukraine }
$$

The relevance of the study of endometrial polyps as one of the clinical forms of endometrial hyperplastic processes, due primarily to the high risk of their malignancy and problems associated with menstrual disorders, 28 